\title{
Using Karaoke to Enhance Recognition of Chinese Words: A Cross-Languages Adoption
}

\author{
Abolfazl Shirban $\mathrm{Sasi}^{1, *}$ \& Shu-Ting $\mathrm{Hsu}^{2}$ \\ ${ }^{1}$ Department of Foreign Languages, National Chiayi University, Taiwan. \\ ${ }^{2}$ Department of General Education, TransWorld University, Taiwan. \\ *Corresponding author: Department of Foreign Languages, National Chiayi University, \\ Chiayi County 62103, Taiwan. Tel: 886-919-456-970. E-mail: Pictologics@gmail.com
}

Received: August 2, 2019 Accepted: August 31, 2019 Published: September 11, 2019

doi:10.5296/ije.v11i3.15431ＵRL: https://doi.org/10.5296/ije.v11i3.15431

\begin{abstract}
This study investigated the effects of Chinese karaoke on recognition and retention of the Chinese characters/words by the Iranian male junior high school learners ( $=61, p<.05)$. In a posttest control group design, students in three English language institutes in Tehran were randomly divided into three groups of Text-only which received the Chinese words via merely a text; Song group which were taught the words via an audio song as well as the text; and finally, Karaoke group which received the words by karaoke, plus the text. The lessons were instructed in two consecutive 20-minute long periods at the end of their routine English classes. The subjects then were tested for their recognition of the 24 Chinese words in question. A One-way ANOVA was run to analyse the scores of the participants. The results revealed that students under Karaoke obtained significantly higher scores as compared to both Text-only and Sound groups. The results, however, did not show any significant difference between the scores of the Text-only and Sound groups. Furthermore, based on the experiment design of this study, this paper advocates consideration of the Arabic writing system as a substitute for the Romanized Pinyin when teaching Chinese to language learners who are familiar with Arabic.
\end{abstract}

Keywords: Character, Chinese, Diacritics, Karaoke, Pinyin, Recognition, Transcription 


\section{Introduction}

It is no mystery that the Chinese language is one of the most difficult among all the other languages. Chinese learners particularly face a lot of difficulties mastering the intensely complex Chinese writing system. In this paper, we try to illustrate a new technique based on usage of well-chosen Chinese Karaoke songs to facilitate remembering and recognizing Chinese characters/words. Ironically, the initial inspiration to design and conduct the current study was the authors' direct observation of teaching/learning reading in two very distant languages; namely, Persian and Arabic. As a multi-century-long tradition in Iran, many older generations used to learn how to read or recite the Holy Koran (the Script for the Muslims). As young children, they would go through a rather strict and rigorous, yet effective method which would provide them with the skill necessary to recognize Arabic words in the Koran (as well as a few other religious texts or lines of prayers). Generally referred to as "Koranic Literacy", this skill could only be used to read/recite religious texts, and would rarely proceed to writing, or reading any other texts.

Likewise, we postulate that applying the steps taken in this study, it is possible to introduce a good number of Chinese characters/vocabulary to the novice learners of Chinese; and thus, preparing them to take bigger steps in their endeavor of learning the Chinese language.

\section{Review of Literature}

\subsection{Arabic, Persian, and Chinese in a Glance}

Persian (or Farsi) belongs to the Indo-European family of languages, while Arabic (the language of Islam) is a Semitic language. On the other hand, Chinese belongs to the Sino-Tibetan family of languages (Katzner, 2002). Persian has adopted the Arabic writing system; therefore, both languages use the same alphabets, and are written from right to left. Nonetheless, there are two significant differences between Arabic and Persian scripts: 1) In Arabic we use diacritics; that is, marks which indicate vowels and final consonants. The most

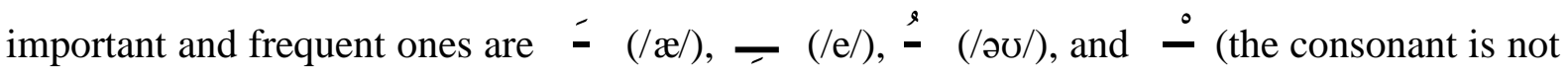
followed by a vowel). Persian, however, does not use these symbols, making its spelling and pronunciation by far more difficult to learn. 2) Persian alphabet contains four more letters and

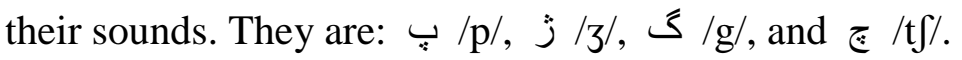

Then, according to $\mathrm{Wu}$ (2016), the Chinese writing system is made of approximately 200 radicals- the most basic elements of Chinese characters-, and also there are over 50,000 Chinese characters out of which 2500 characters are necessary for basic literacy. There have been numerous attempts, or remedies to facilitate learning Chinese characters/words, some of which are: creating a story or stories for each individual character or word (Heisig \& Richardson, 2009, 2012); discovering patterns in Chinese characters (Anderson et al., 2013); providing the logical and historical origins of every character ( $\mathrm{Wu}, 2016)$; and finally several online programs providing tools like Chinese word grids and matrixes, like in (Learn to recognize and write Chinese characters, www.digmandarin.com). 


\subsection{Applying Music and Songs in Language Pedagogy}

According to Wallace (1994), using songs with simple patterns can enhance text recall in the learners' first language. Music has also been directly integrated into the language teaching method in Desuggestopedia (Larsen-Freeman \& Anderson, 2011). Music can have a positive effect both verbally and non-verbally in providing a boost in psycho-physiological stimulation and mood (Cassidy \& MacDonald, 2007; Jones, West, \& Estell, 2006; Schellenberg, 2006). Music is also assumed to be an effective aid to enhance memory (Legg, 2009; Thiessen \& Saffran, 2009). There are also other cognitive neurological studies which suggest that music has significant effect on linguistic memory and thus, enhancement of language tasks (Jentschke, Koelsch, \& Friederici, 2005; Patel, 2008; Sammler et al., 2010). Borchgrevink (1982) assumed that linguistic and musical elements are processed in different hemispheres in our brain and thus, language and music that are presented simultaneously can provide effective pedagogical methodology to enhance learning. There have also been several experiments and investigations resulting that music and songs can provide positive emotions and learning improvements for language learners (Lozanov \& Gateva, 1989; Spicher \& Sweeney, 2007; and Ting, 2002). Likewise, Besson, Chobert, and Marie (2011) argue that music and language must have had common origin with common primary function to express emotions. Daltrozzo and Schon (2009) demonstrated that there is a shared processing phase between language and music at the conceptual level. Then, Aguirre, Bustinza, and Garvich (2016) studied the eff ects of music when added to the language class syllabus. The results showed that students were motivated more to take part in the class activities when songs were used in their English classes. In an attempt to make use of karaoke type techniques in teaching languages, Bailly and Barbour (2011) investigated the potential usage of a karaoke-style reading system for learning sound-to-letter mapping in French. They developed a platform that enhances the development of interactive systems by exploiting the configuration of text with audio counterparts at several levels such as; letters, phones syllables, words, and chunks. Also, in a study on the effects of using karaoke on learning Japanese vocabulary by the Taiwanese university students, Shirban Sasi and Haga (2019) found that only female learners revealed a significant improvement. Furthermore, Hansen and Bernstrof (2002) deliberated on the positive effects of music on reading attainment. Also conducting meta-analysis studies examining reading achievement and music, Butzlaff (2000) found correlations between the two. Finally, there are several resources on the Internet for teaching/learning languages via, or by the help of music and songs. A good example which combines practice and theory is the Internet TESL Journal. Some pertinent samples of the articles, lessons, or techniques on this site are: (Ahola, 2005; Cullen, 1998; Cakir, 1999; Orlova, 2003; and Saricoban \& Metin, 2000).

On the other end of the spectrum, however, there are speculations that disruptive music would make extra demands on the limited processing abilities of cognitive systems, thus reducing existing resources for other parallel tasks to function sufficiently (Kämpfe, Sedlmeier, \& Renkewitz, 2010; Schellenberg, 2012). In other words, music might have negative effects on language learning. 


\section{Material and Methods}

The purpose of the data collected in this study was to investigate the effects of applying karaoke in helping Iranian junior high school students recognize and remember Chinese words.

\subsection{Participants}

A total of 61 students participated in this study. They were three groups of students (age 1114) in three different boys English language institutes located in the same district in the north of Tehran. They were all studying at lower intermediate English level. The three classes were randomly divided into Sound (18 students), Karaoke (20 students), and Written-text (23 students) groups in separate language institutes. The reason for selecting these English learners instead of Chinese learners is simply that there are no young learners of Chinese in Iran at all! Chinese is just taught in perhaps one or two universities in the whole country. Thus, these samples had absolutely zero knowledge of Chinese prior to this experiment.

\subsection{Instruments}

There are almost countless Chinese karaoke songs available online; however, given the restricted regulations for the usage of music in Iran, particularly in the education sector, the researchers had to be very careful when selecting a suitable karaoke song. Consequently, what was ultimately used was a song called Endless Love on the film trailer from the movie The Myth by the popular star Jackie Chan (2005) accessible at https://www.youtube.com/watch?v=mtY8E_7eF1o\&list. The whole karaoke song version is 04:50 minutes long, out of which 01:30 minutes are in Korean. In this study, only the Chinese parts (03: 20 mins) were edited out of the trailer and used. The song contains 190 Chinese characters/words written in 24 lines. For the sake of this study, the researchers randomly picked one non-repeated word in each line and highlighted them together with the English and Persian translations and Arabic transcription (Table 1). The reason why we used Arabic is because, as mentioned in the introduction, Persian writing does not show vowels, and so makes it almost impossible to transcribe words. However Arabic diacritics are great help to transcribe closely native-like pronunciations for the original Chinese words. Iranian students frequently use this technique to learn and remember the pronunciation of foreign words when studying them for the first time.

As can be seen in Table 1, we did not provide the students with Pinyin (Romanized) transcription of the Chinese words in order to avoid confusion. However, for further reference, please find this list along with the Pinyin as well as Persian transcription of the Chinese words in Appendix 1.

Additionally, in order to assess how many of the Chinese characters/words the participants in the three groups learnt, all 24 words designated in this experiment were put in a written test at the end of the treatment. The words were randomized on a list and the students were required to provide either English or Persian equivalents for the Chinese words (Appendix 2). 
Table 1. The Song Lyrics with English and Persian Translation and Arabic Transcription

\begin{tabular}{|c|c|c|c|}
\hline Chinese Lines & English Translation & $\begin{array}{l}\text { Word Arabic } \\
\text { Transcription }\end{array}$ & Persian Translation \\
\hline 解开我最神秘的等待 & $\begin{array}{l}\text { Release me from this } \\
\text { mysterious waiting, }\end{array}$ & 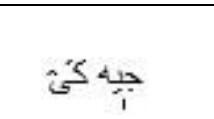 & كر ا از اين انتظار مرموز رها \\
\hline 星星坠落风在吹动 & $\begin{array}{l}\text { The stars are falling, the wind is } \\
\text { blowing. }\end{array}$ & نضin & وزتاره ها ميفتند، باد مى \\
\hline 终于再将你拥入怀中 & $\begin{array}{l}\text { Finally I can hold you in my } \\
\text { arms, }\end{array}$ & 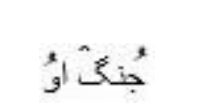 & 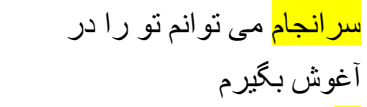 \\
\hline & Two hearts beating together. & لياترك & دو قلب درتيش كنار هم. \\
\hline 相信我不变的真心 & $\begin{array}{l}\text { Believe me that my heart has } \\
\text { never changed, }\end{array}$ & 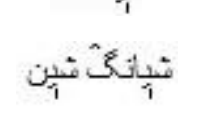 & نكرده است قلب من هركز تغيير \\
\hline 千年等待有我承诺 & $\begin{array}{l}\text { Waiting a thousand years, you } \\
\text { have my promise. }\end{array}$ & جى بربن & نو هز ارسال انتظار ، و عده من به \\
\hline 无论经过多少的寒冬 & Despite many cold winters, & $\xi \hat{i j}$ & ساودود زمستان هاى بسيار \\
\hline $\begin{array}{l}\text { 我决不放手 } \\
\text { 每一夜被心痛穿越 } \\
\text { 思念永没有终点 }\end{array}$ & $\begin{array}{l}\text { I will never let you go. } \\
\text { Every night my heart aches, } \\
\text { I never stop thinking of you. }\end{array}$ & فورين & 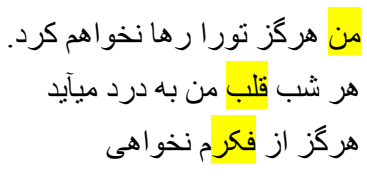 \\
\hline 早习惯了孤独相随 & $\begin{array}{l}\text { I am used to being lonely for } \\
\text { such a long time, }\end{array}$ & كُونو & رنت \\
\hline $\begin{array}{l}\text { 我微笑面对 } \\
\text { 相信我我选择等待 } \\
\text { 再多苦痛也不闪躲 }\end{array}$ & $\begin{array}{l}\text { And I face it with a smile. } \\
\text { Believe me, I choose to wait, } \\
\text { Even though it's painful, I }\end{array}$ & 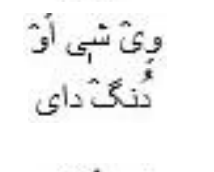 & 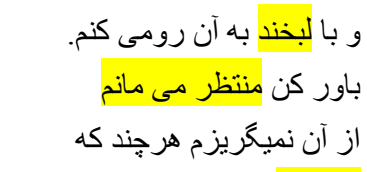 \\
\hline & won't dodge. & كو كُنُ & دردناك است. \\
\hline 只有你的温柔能解救 & $\begin{array}{l}\text { Only your tenderness can save } \\
\text { me }\end{array}$ & 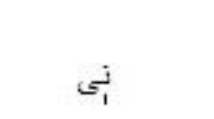 & بر فقط مهربانى تو مى نو اند مرا \\
\hline 无边的冷漠 & From the endless cold. & وي بي برِن به & 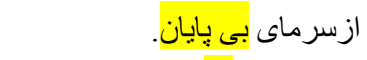 \\
\hline 让爱成为你我心中 & Let the love in our hearts & ح: & بكذار عشق درقلب ما \\
\hline 那永远盛开的花 & Become a blossoming flower. & 19 & جون كلى شكوفا شود. \\
\hline 穿越时空绝不低头 & $\begin{array}{l}\text { We can pass through time, } \\
\text { never bowing our heads, }\end{array}$ & تَى & وهى تو انيم اززمان كذر كنيم \\
\hline 永不放弃的梦 & And never giving up our dream. & S: & وهركزيم. \\
\hline 唯有真爱追随你我 & Only true love follows us, & جن & كقط عشق و اقعى ما را دنبال مى \\
\hline 穿越无尽时空 & $\begin{array}{l}\text { Through endless space and } \\
\text { time. }\end{array}$ & جوبان & از ميان فضاو زمان بى كران. \\
\hline 爱是心中唯一 & $\begin{array}{l}\text { The love in our hearts is the } \\
\text { only }\end{array}$ & وئى برى & عثق ما در دل ما تنها \\
\hline 不变美丽的神话 & Unchanging myth. & تشنث هورا & تغييرنايذير است است كه. \\
\hline
\end{tabular}




\subsection{Procedure}

As mentioned, the participants in this study were in three groups randomly divided into Sound, Karaoke, and Written-text. All three were given a handout of the Chinese song with English and Persian translations and the words highlighted (the text $=$ Table 1). All three groups spent two consecutive sessions learning the Chinese words with an interval of three days. The time allocated was the last 20 minutes of their usual English classes in the language institutes. The Written-text group were asked to study the text only (Table 1) during this period. While, the Sound group would listen to the song track for two times when studying the text as well. The Karaoke group, however, also watched the edited Chinese karaoke for two times in each session along with studying the text. The teachers in all three groups had been instructed to help the students with the meaning or pronunciations of the Chinese words using both English and Persian if necessary. The students were required to study the words at home to get prepared for a Chinese vocabulary test on the third session. It was clearly emphasised that the aim of the test was merely to recognize the Chinese characters/words, and not to pronounce or write them.

\subsection{Research Question and Hypothesis}

RQ: Is there any significant difference among the results of teaching methods of the Chinese characters/words in the sample groups?

Ho: Among the three sample groups of learners in this study, the teaching methods of the Chinese characters/words will yield equal results.

$\mathrm{H}_{\mathrm{A}}$ : Among the three sample groups of learners in this study, the teaching methods of the Chinese characters/words will yield some different results.

\section{Results}

Since the statistical test used in the current study was a One-way ANOVA, then the three assumptions of independence of observations, normality of the results distribution, and homogeneity of the variances had to be met. As mentioned before, the study samples were randomly assigned in three different same level, same age boys language institutes. Thus, the assumption of the independence of observations was completely met in this study.

Then as for the normality of the distribution of the scores in the population, we should look at the descriptive statistics results including the K-S test as shown in Table 2.

Table 2 shows that the mean of 4.80 is very close to the median of 5.00 in the groups. This indicates that the scores are almost normally distributed. We can also look at the skewness statistics. Here, we can see that the skewness value of .142 is small relative to the standard error of .306, so the skewness is not a problem here. Likewise, the Kurtosis value of -.297 is also small as compared with the standard error of .604, suggesting that the Kurtosis is not problematic, either. 
Table 2. Descriptive Statistics for the Scores

\begin{tabular}{lllrr}
\hline & & \multicolumn{1}{c}{ Statistic } & \multicolumn{1}{c}{ Std. Error } \\
\hline VAR00001 & Mean & 4.8033 & .33699 \\
& $95 \%$ Confidence Interval for & Lower Bound & 4.1292 & \\
\cline { 2 - 3 } & Mean & 5.4774 & \\
\cline { 2 - 3 } 5\% Trimmed Mean & 4.7641 & \\
Median & & 5.0000 & \\
Skewness & .142 & .306 \\
Kurtosis & -.297 & .604 \\
\hline
\end{tabular}

Furthermore, the K-S test of normality revealed a significant $p$ value of .200 suggesting that the distribution of scores is normal.

Then, for the homogeneity of observations we can see the Levene's Test, as shown in Table 3:

Table 3. Levene's Test of Equality of Error Variances

\begin{tabular}{cccc}
\hline $\mathrm{F}$ & $\mathrm{df} 1$ & $\mathrm{df} 2$ & Sig. \\
\hline .086 & 2 & 58 & .918 \\
\hline
\end{tabular}

We can see in Table 3 that the $p$ value of .918 yields a non-significant result. In other words, it the assumption of homogeneity of observations has been met in the current study.

Thus, all three assumptions for a One-way ANOVA are sustained in the present study.

Then, running the One-way ANOVA statistical test including the Scheffe Post Hoc test, we can see the results as follows in Table 4:

Table 4. Tests of Between-Subjects Effects

\begin{tabular}{lcccccc}
\hline & Type III Sum of & & & & \\
Source & Squares & df & Mean Square & F & Sig. & Partial Eta Squared \\
\hline Corrected Model & $135.594^{\mathrm{a}}$ & 2 & 67.797 & 14.041 & .000 & .326 \\
Intercept & 1427.678 & 1 & 1427.678 & 295.686 & .000 & .836 \\
Group & 135.594 & 2 & 67.797 & 14.041 & .000 & .326 \\
Error & 280.045 & 58 & 4.828 & & & \\
Total & 1823.000 & 61 & & & \\
Corrected Total & 415.639 & 60 & & & \\
\hline
\end{tabular}

As seen in Table 4, the significance level for $\mathrm{F}$ for the Group equals .000, which is lower than the $\alpha$ value level of .05 . This suggests that the test result is statistically significant. Thus, we can deduce that there are some significant difference among the scores gained by the 


\section{Al Macrothink}

members of the groups in this study. Therefore, the Null hypothesis has been rejected. That is, there is some significant differences among the three groups in this study.

$$
\text { So, we will have: } \mathrm{F}(2,58)=14.04, \mathrm{p}<.05
$$

As for the magnitude of the associations among the groups, or the effect size, we see that the Eta Squared value in Table 4 is.326. According to Cohen (1988), we can interpret this value as: $.01=$ small effect, $.06=$ moderate effect, and $.14=$ large effect. Thus, we would claim that the effect size of .326 for this test is rather a large effect.This value reveals the proportion of the score variance in the recognition of the Chinese words among the sample groups. If we multiply this number by 100 , then we can say that in our sample, $32.6 \%$ of the variance in Chinese words recognition scores is related to the type of teaching/presenting these words to the students.

Furthermore, we can look at the results of the Scheffe Post Hoc test in order to determine where the differences lie in Table 5 below:

Table 5. Results of Scheffe Post Hoc Test

\begin{tabular}{llccccc}
\hline (I) & (J) Group & $\begin{array}{c}\text { Mean Difference } \\
\text { Group }\end{array}$ & & Std. Error & Sig. & \multicolumn{2}{c}{ 95\% Confidence Interval } \\
\cline { 6 - 7 } Karaoke & Sound & $2.4611^{*}$ & .71391 & .004 & .6675 & 4.2547 \\
& Text only & $3.5022^{*}$ & .67182 & .000 & 1.8143 & 5.1900 \\
\multirow{2}{*}{ Sound } & Karaoke & $-2.4611^{*}$ & .71391 & .004 & -4.2547 & -.6675 \\
& Text only & 1.0411 & .69150 & .329 & -.6962 & 2.7783 \\
\multirow{2}{*}{ Text-onl } & Karaoke & $-3.5022^{*}$ & .67182 & .000 & -5.1900 & -1.8143 \\
$\mathrm{y}$ & Sound & -1.0411 & .69150 & .329 & -2.7783 & .6962 \\
\hline
\end{tabular}

As evident in Table 5, the Karaoke group reveals a significant difference with both Sound and Text-only groups. However the scores difference between the Sound group and the Text-only group is not statistically significant. These differences are visually illustrated in Figure 1 below. 


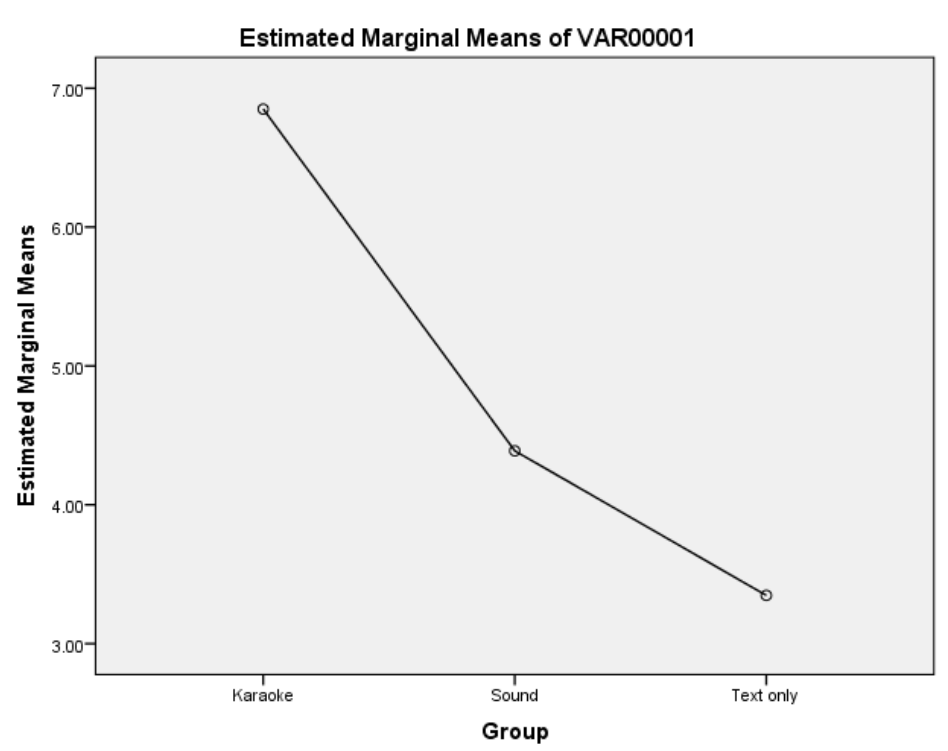

Figure 1. Differences of Students' Scores among the Three Groups in the Current Study

\section{Discussion}

The current study dealt with the usage of Chinese karaoke songs in enhancing teaching/learning Chinese characters/words. Despite the very short period of the experiment, the data revealed that those learners who were taught the Chinese words through karaoke learnt significantly better than those who just listened to the song, or only studied the song lyrics in a written text. We did not interview the students as to discover whether they simply enjoyed watching the Chinese karaoke or not. If they did, then the findings of this study would support the claims of the scholars like Cassidy and MacDonald (2007); Jones, West, and Estell (2006); and Schellenberg (2006) in that music can have a positive influence on providing a boost in psycho-physiological stimulation and mood. The present findings are also in concord with the assumptions of Legg (2009); and Thiessen and Saffran (2009) in that music is an effective tool to enhance memory. We also postulate that merely watching karaoke in Chinese might have had positive effects on the students simply by motivating them to study and review the Chinese characters/words at home during the two 3-day intervals between the sessions and the test. If this be true, then we might claim that music and karaoke can act as effective motivational means on language learners. This is in harmony with the finding of Aguirre, Bustinza, and Garvich (2016).

Due to the small sample size, we did not compare male and female language learners. Nonetheless, the findings here disagree with the results of Shirban Sasi and Haga (2019) in that only female students, and not the male ones, were positively affected by karaoke songs. Moreover, contrary to the claims of Kämpfe, Sedlmeier, and Renkewitz (2010); and Schellenberg (2012), the current study did not depict any negative effects on the language learners. 


\section{Limitations of the Study}

As mentioned before, due to the restricted regulations imposed in language institutes in Iran, the time of each session, as well as the total duration of this study was very limited. Also, we could not target more students. Neither were we able to study female students. Furthermore, we were bound to choose from a very narrow range of karaoke songs due to the current constrained laws for usage of music in the Iranian society, particularly in education sector.

\section{Recommendations for Future Research}

Based on the above-mentioned limitations, and also given the multifaceted subject area of the current study, the authors recommend the followings for further future research:

- studying female vs. male students learning Chinese characters/words via karaoke;

- applying various types of Chinese karaoke songs for native speakers of other languages;

- studying the possibility and feasibility of using Arabic phonetic transcription as a potential replacement fro Romanized Pinyin systems for Muslim countries;

- studying probable enhancement of Chinese language learners' other skills such as, speaking, and listening by using Chinese Karaoke songs.

\section{Conclusion}

The present study supported that karaoke songs could be used to teach students recognition, and enhance their remembering Chinese characters and words, even when these learners have zero background and knowledge of Chinese. The authors are positive that by utilizing the steps taken in the present study, it is possible to teach many Chinese characters/vocabulary to the language learners, specially the beginners. Furthermore, the design of this study illustrated an effective usage of the Arabic language writing system with its diacritics to phonetically transcribe the Chinese characters/words. The authors suggest that this can be a good substitution, or at least a complementary tool, for the somehow confusing Romanized Pinyin systems currently used in teaching/learning Chinese. Given that Arabic is the language of Islam, there are hundreds of millions of people who are either native speakers of Arabic, or at least familiar with this language.

\section{References}

Aguirre, D., Bustinza, D., \& Garvich, M. (2016). Influence of songs in primary school students' motivation for learning English in Lima, Peru. English Language Teaching, 9(2), 178-191. http://www.ccsenet.org/journal/index.php/elt

Ahola, S. (2005). Digger Deeper into Songs: A Writing Activity. The Internet TESL Journal, XI(2). Retrieved April 15, 2019, from http://iteslj.org 
Anderson, R. C., Ku, Y. M., Li, W., Chen, X., \& Hua Shu, X. W. (2013). Learning to See the Patterns in Chinese Characters. Scientific Studies of Reading, 17, 41-56. https://doi.org/10.1080/10888438.2012.689789.

Bailly, G., \& Barbour, W. S. (2011). Synchronous reading: learning French orthography by audiovisual training. 12th Annual Conference of the International Speech Communication Association (Interspeech 2011), Aug 2011, Florence, Italy. pp. 1153-1156. Hal-00618780.

Besson, M., Chobert, J., \& Marie, C. (2011). Transfer of training between music and speech: common processing, attention, and memory. Frontiers in Psychology, 2(94), 147-158. https://doi.org/10.3389/fpsyg.2011.00094

Borchgrevink, H. (1982). Prosody and musical rhythm are controlled by the speech hemisphere. In Clyne, M. (Ed.), Music, Mind, and Brain: The Neuropsychology of Music (pp. 151-157). New York: Plenum.

Butzlaff, R. (2000). Can music be used to teach reading? Journal of Aesthetic Education, 34(3-4), 167-78.

Cakir, A. (1999). Musical Activities for Young Learners of EFL. The Internet TESL Journal, $V(11)$. Retrieved April 15, 2019, from http://iteslj.org.

Cassidy, G., \& MacDonald, R. (2007). The effect of background music and background noise on the task performance of introverts and extraverts. Psychology of Music, 35(3), 517-537. https://doi.org/10.1177/0305735607076444

Chan, J. (Producer), \& Tong, S. (Director). (2005). The Myth [Motion Picture]. Hong Kong: JCE Movies Limited.

Cohen, J. (1988). Statistical power analysis for the behavioral sciences. Hillsdale, NJ: Erlbaum.

Cullen, B. (1998). Music and Song in Discussion. The Internet TESL Journal, IV(10). Retrieved April 15, 2019, from http://iteslj.org.

Daltrozzo, J., \& Schon, D. (2009). Conceptual processing in music as revealed by n400 effects on words and musical targets. Journal of Cognitive Neuroscience, 21(10), 18821892. https://doi.org/10.1162/jocn.2009.21113

Hansen, D., \& Bernstorf, E. (2002). Linking music learning to reading instruction. Music Educators Journal, 88(5), 17-22. https://doi.org/10.2307/3399821

Heisig, J. W., \& Richardson, T. W. (2009). Remembering traditional Hanzi: How not to forget the meaning and writing of Chinese characters. Book 1. Honolulu: University of Hawaii Press.

Heisig, J. W., \& Richardson, T. W. (2012). Remembering traditional Hanzi: How not to forget the meaning and writing of Chinese characters. Book 2. Honolulu: University of Hawaii Press. 
Jentschke, S., Koelsch, S., \& Friederici, A. D. (2005). Investigating the relationship of music and language in children: Influences of musical training and language impairment. Annals of the New York Academy of Sciences, 1060, 231-242. https://doi.org/10.1196/annals.1360.016

Jones, M. H., West, S. D., \& Estell, D. B. (2006). The Mozart effect: Arousal, preference, and spatial performance. Psychology of Aesthetics, Creativity, and the Arts, s(1), 26-32. https://doi.org/10.1037/1931-3896.S.1.26

Katzner, K. (2002). The languages of the world. London: Routledge and Kegan Paul Ltd. https://doi.org/10.4324/9780203430163

Kämpfe, J., Sedlmeier, P., \& Renkewitz, F. (2010). The impact of background music on adult listeners: A meta-analysis. Psychology of Music, 39(4), 424-448. https://doi.org/10.1177/0305735610376261

Larsen-Freeman, D., \& Anderson, M. (2011). Techniques \& principles in language teaching (3rd ed.). Oxford: Oxford University Press.

Learn to recognize and write Chinese characters. (n. d.) Retrieved from www.digmandarin.com.

Legg, R. (2009). Using music to accelerate language learning: an experimental study. Research in Education, 82(1), 1-12. https://doi.org/10.7227/RIE.82.1

Lozanov, G., \& Gateva, E. (1989). The Foreign Language teacher's Suggestopedic Manual. Montreux, Switzerland: Gordon \& Breach Science Publishers.

Orlova, N. (2003). Helping Prospective EFL Teachers Learn How to Use Songs in Teaching Conversation Classes. The Internet TESL Journal, IX (3). Retrieved April 15, 2019, from http://iteslj.org.

Patel, A. D. (2008). Music, language and the brain. Oxford: Oxford University Press.

Sammler, D., Baird, A., Valabregue, R., Clement, S., Dupont, S., Belin, P., \& Samson, S. (2010).The relationship of lyrics and tunes in the processing of unfamiliar songs: An fMR adaptation study. Journal of Neuroscience, 10, 3572-3578.

Saricoban, A., \& Metin, E. (2000). Songs, Verse and Games for Teaching Grammar. The Internet TESL Journal, VI (10). Retrieved April 15, 2019, from http://iteslj.org.

Schellenberg, E. G. (2006). Exposure to music: The truth about the consequences. In G. E. McPherson (Ed.), The child as musician: A handbook of musical development (pp. 111134). Oxford, UK: Oxford University Press.

Schellenberg, E. G. (2012). Cognitive performance after music listening: A review of the Mozart effect. In R. A. R. MacDonald, G. Kreutz, \& L. Mitchell (Eds.), Music, health and wellbeing (pp. 324-338). Oxford, UK: Oxford University Press.

Shirban Sasi, A., \& Haga, T. (2019). Using karaoke videos to teach Japanese vocabulary to 
Taiwanese university students. Journal of Language Teaching and Research, 10(1), 51-59. https://doi.org/10.17507/jltr.1001.06

Spicher, L., \& Sweeney, F. (2007). Folk music in the L2 classroom: Development of nativelike pronunciation through prosodic engagement strategies. Connections: $a$ journal for foreign language educators, 1, 35-48.

Thiessen, E. D., \& Saffran, J. R. (2009). How the melody facilitates the message and vice versa in infant learning and memory. The Neurosciences and Music III - Disorders and Plasticity: Annals of the New York Academy of Sciences, 1169, 225-233. https://doi.org/10.1111/j.1749-6632.2009.04547.x

Ting, Y. L. T. (2002). An in-house training session on the use of songs. Humanising Language Teaching, 4(2), 1-11.

Wallace, W. T. (1994). Memory for music: Effect of melody on recall of text. Journal of Experimental Psychology: Learning, Memory, and Cognition, 20(6), 1471-1485. https://doi.org/10.1037/0278-7393.20.6.1471

$\mathrm{Wu}, \mathrm{J} . \mathrm{H}$. (2016). The way of Chinese characters: the origins of 670 essential words. Boston, MA: Cheng \& Tsui Company, Inc. 
Appendix 1. Chinese words with their English Translations, as well as Arabic, Persian, and Pinyin transcriptions

\begin{tabular}{|c|c|c|c|c|}
\hline Chinese Word & Pinyin Transcription & $\begin{array}{c}\text { Persian } \\
\text { Transcription }\end{array}$ & $\begin{array}{c}\text { Arabic } \\
\text { Transcription }\end{array}$ & $\begin{array}{c}\text { English } \\
\text { Translation }\end{array}$ \\
\hline 解开 & Jiě kāi & جيه كى & جئ كَئ & release \\
\hline 星星 & Xīngxīng & شينـ شينى & 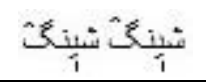 & stars \\
\hline 终于 & Zhōngyú & جنى او & 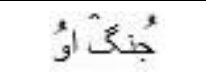 & finally \\
\hline 两 & Liăng & ليانگ & ليانك & two \\
\hline 相信 & Xiāngxìn & شيانـ شين & ثنبان & believe \\
\hline 千 & Qiān & 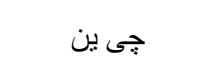 & جَى بِن & a thousand \\
\hline 冬 & Dōng & دونغ & دُونَى & winter \\
\hline 我 & Wǒ & ووا & وروا & I \\
\hline 心 & Xīn & شين & تبنين & heart \\
\hline 思 & $\mathrm{S} \overline{1}$ & 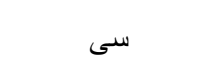 & ज्ञ & thinking \\
\hline 孤独 & Gūdú & 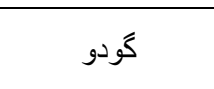 & كو' & lonely \\
\hline 微笑 & Wéixiào & وى شى او & ويى شِى أو & smile \\
\hline 等待 & Děngdài & دنع داى & دنكُداى & wait \\
\hline 苦痛 & Kǔtòng & كو تتش & كو نُك & painful \\
\hline 你 & Nĩ & 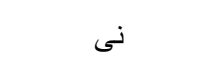 & نَى & your \\
\hline 无边的 & Wúbiān de & وو بى ين ده & وي بى بِن بـ & endless \\
\hline 中 & Zhōng & جنى & جُنَ & In \\
\hline 花 & Huā & هووا & هos & flower \\
\hline 时 & Shí & 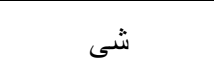 & تَى & time \\
\hline 的梦 & De mèng & د د منى & נد & dream \\
\hline 真 & Zhēn & جن & جִن & true \\
\hline 穿 & Chuān & جووان & جوقان & through \\
\hline 唯一 & Wéiȳ̄ & 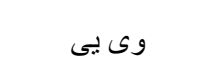 & وئَ بِى & only \\
\hline 神话 & Shénhuà & شن هووا & بتن هورا & myth \\
\hline
\end{tabular}




\section{Macrothink}

Appendix 2. Test of Chinese Words

* Please write an English or a Persian translation for each of the following Chinese words in the right column. Thanks.

* لطفاً ترجمه هر يك از كلمات جينى زير را به انكليسى يا فارسى در ستون سمت راست بنويسيد. با تشكر.

\begin{tabular}{|c|c|l|}
\hline & Chinese Word: & Your Translation: \\
\hline 1 & 终于 & \\
\hline 2 & 千 & \\
\hline 3 & 思 & \\
\hline 4 & 我 & \\
\hline 5 & 星星 & \\
\hline 6 & 等待 & \\
\hline 7 & 孤独 & \\
\hline 8 & 两 & \\
\hline 9 & 冬 & \\
\hline 10 & 时 & \\
\hline 11 & 解开 & \\
\hline 12 & 中 & \\
\hline 13 & 微笑 & \\
\hline 14 & 真 & \\
\hline 15 & 相信 & \\
\hline 16 & 的梦 & \\
\hline 17 & 心 & \\
\hline 18 & 你 & \\
\hline 19 & 穿 & \\
\hline 20 & 无边的 & \\
\hline 21 & 神话 & \\
\hline 22 & & \\
\hline 23 & 花 & \\
\hline 24 & & \\
\hline
\end{tabular}

\section{Copyright Disclaimer}

Copyright for this article is retained by the author(s), with first publication rights granted to the journal.

This is an open-access article distributed under the terms and conditions of the Creative Commons Attribution license (http://creativecommons.org/licenses/by/3.0/). 